$$
\begin{gathered}
\text { BNL }-64029 \\
\text { CONF- } 96 / 202--102
\end{gathered}
$$

Enumeration of Microbial Populations in Radioactive Environments by Epifluorescence Microscopy

M.E. Pansoy-Hjelvik', B.A. Strietelmeier', M.T. Paffett', S.M. Kitten', P.A. Leonard', M. Dunn ${ }^{2}$, J.B. Gillow ${ }^{2}$, C.J. Dodge ${ }^{2}$, R. Villarreal' ${ }^{1}$ I.R. Triay ${ }^{1}$, and A.J. Francis ${ }^{2}$

$$
\begin{gathered}
\text { 'Los Alamos National Laboratory } \\
\text { CST-7MS J514 } \\
\text { Los Alamos, NM } 87544 \\
\text { and } \\
\text { 'Department of Applied Science } \\
\text { Brookhaven National Laboratory } \\
\text { Upton, NY } 11973
\end{gathered}
$$

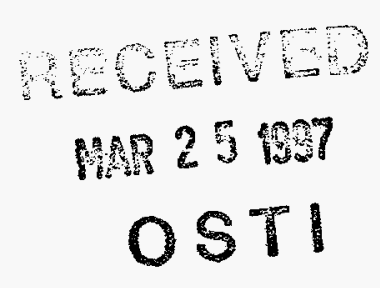

January 1997

Fall Meeting of the Materials Research Society, Scientific Basis for Nuclear Waste Management XX

$$
\text { Boston, MA }
$$

December 2-6, 1996

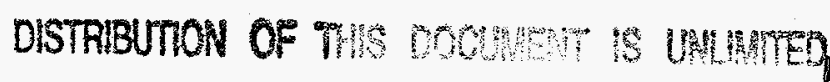

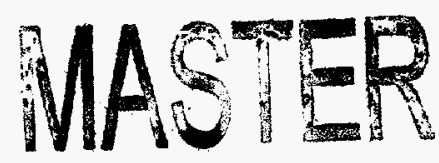

This research was performed under the auspices of the U.S. Department of Energy under Contract No. DE-AC02-76CH00016. 


\section{DISCLAMERT}

Portions of this document may be illegible in electronic inage products. Images are produced from the best available original document. 


\section{DISCLAIMER}

This report was prepared as an account of work sponsored by an agency of the United States Government. Neither the United States Government nor any agency thereof, nor any of their employees, make any warranty, express or implied, or asumes any legal liability or responsibility for the accuracy, completeness, or usefulness of any information, apparatus, product, or process disclosed, or represents that its use would not infringe privately owned rights. Reference herein to any specific commercial product, process, or service by trade name, trademark, manufacturer, or otherwise does not necessarily constitute or imply its endorsement, recommendation, or favoring by the United States Government or any agency thereof. The views and opinions of authors expressed herein do not necessarily state or reflect those of the United States Government or any agency thereof. 


\title{
ENUMERATION OF MICROBIAL POPULATIONS IN RADIOACTIVE ENVIRONMENTS BY EPIFLUORESCENCE MICROSCOPY
}

\author{
M.E. PANSOY-HJELVIK*, B.A. STRIETELMEIER*, M.T. PAFFETT*, S.M. KITTEN*, \\ P.A. LEONARD*, M. DUNN**, J.B. GILLOW**, C.J. DODGE**, R. VILLARREAL*, I.R. \\ TRIAY* , and A.J. FRANCIS**. *Los Alamos National Laboratory, CST-7 MS J514, Los \\ Alamos, NM 87544, meph@lanl.gov. **Brookhaven National Laboratory, PO 5000, Bldg. 318, \\ Upton, NY 11973
}

\begin{abstract}
Epifluorescence microscopy was utilized to enumerate halophilic bacterial populations in two studies involving inoculated, actual waste/brine mixtures and pure brine solutions. The studies include an initial set of experiments designed to elucidate potential transformations of actinide-containing wastes under salt-repository conditions, including microbially mediated changes.
\end{abstract}

The first study included periodic enumeration of bacterial populations of a mixed inoculum initially added to a collection of test containers. The contents of the test containers are the different types of actual radioactive waste that could potentially be stored in nuclear waste repositories in a salt environment. The transuranic waste was generated from materials used in actinide laboratory research. The results show that cell numbers decreased with time. Sorption of the bacteria to solid surfaces in the test system is discussed as a possible mechanism for the decrease in cell numbers.

The second study was designed to determine radiological and/or chemical effects of $239 \mathrm{Pu}$, $243 \mathrm{Am}, 237 \mathrm{~Np}, 232 \mathrm{Th}$ and $238 \mathrm{U}$ on the growth of pure and mixed anaerobic, denitrifying bacterial cultures in brine media. $\mathrm{Pu}, \mathrm{Am}$, and $\mathrm{Np}$ isotopes at concentrations of $\leq 1 \times 10^{-6} \mathrm{M}, \leq 5 \times 10^{-6} \mathrm{M}$ and $\leq 5 \times 10^{-4} \mathrm{M}$ respectively, and $\mathrm{Th}$ and $\mathrm{U}$ isotopes $\leq 4 \times 10^{-3} \mathrm{M}$ were tested in these media. The results indicate that high concentrations of certain actinides affected both the bacterial growth rate and morphology. However, relatively minor effects from Am were observed at all tested concentrations with the pure culture.

\section{INTRODUCTION}

Epifluorescence microscopy has been used to count bacterial populations in two studies related to the disposal of transuranic (TRU) radioactive waste [1,2]. The motivation for the microscopy studies was to determine the relevant microbially-influenced system variables which could be crucial with respect to transuranic waste repositories. Bacteria present at potential TRU waste disposal sites can play roles in, for example, 1) actinide retardation or transport [2], 2) biological transformation of organic or inorganic materials in radioactive waste containers [3], and 3) gas generation due to bacterial metabolic activity [4]. Prior to addressing any of these variables, it is first necessary to confirm the presence of the bacteria and to quantify their populations.

In the first study, bacterial total numbers were determined in tests of actual low-level transuranic waste under high-ionic strength environmental conditions. Test containers at Los Alamos National Laboratory (LANL) hold miscellaneous laboratory items used in actinide research such as gloves, cellulosic materials, plastics, etc. In addition, solidified inorganic process sludge, pyrochemical salts, and various cementous materials were added to the different containers [5]. Large (55-gal sized) drums and small (2-3 liter sized) titanium test containers hold the varying types of material. A mixed bacterial inoculum, composed of muck pile salt, hypersaline lake brine, and sediment slurry was prepared by Brookhaven National Laboratory and added to the test containers. Synthetic brines similar to brines that could be found at potential salt-based radioactive waste repositories was also added to the containers.

In the second study, pure and mixed anaerobic, denitrifying bacterial cultures isolated by BNL from a salt environment were used [4]. Actinides of varying concentrations were added to the growth media prior to inoculation with the bacterial cultures. Cell numbers were measured as a function of incubation time in the growth cycle of each culture and as a function of actinide 
concentration. From monitoring temporal data, growth curves of the individual cultures were generated, and radiological or chemical effects of the actinides to the cultures were observed as trends in the curves. These types of effects are important factors underlying actinide retardation or transport by bacteria. This study included identifying the effects to the two cultures when exposed to $239 \mathrm{Pu}, 243 \mathrm{Am}, 237 \mathrm{~Np}, 232 \mathrm{Th}$ and $238 \mathrm{U}$ isotopes and employed turbidimetric, liquid scintillation and $\mathrm{pH}$ measurements, in addition to epifluorescence microscopy $[1,2]$. We report herein only bacterial cell counts for studies of the pure culture with $\mathrm{Pu}$ and $\mathrm{Am}$.

Epifluorescence microscopy offers several advantages when working with radioactive or hazardous samples [6,7]. Small volumes of the samples are used (typically 0.01 to $0.50 \mathrm{ml}$ ) and as a result, there is minimal radioactive waste generation and minimal radiological exposure to the analyst. Additionally, analysis time is rapid. These two features are in contrast to the larger sample volumes and ancillary materials that end up as waste, the much longer growth and analysis time required with plate count methods, and the increased potential for exposure to personnel.

\section{EXPERIMENTAL}

Epifluorescence microscopy [8], when used with the appropriate fluorochrome, allows for the visualization of the smallest bacterial cells as well as the ability to differentiate them from nonmicrobial debris. The Zeiss Axioscope and the specific objective used in the studies gives a 1000fold overall magnification. Accurate field of view determinations were made using either a NIST traceable micrometer or from measurements of transmitted light through TEM calibration grids.

In the data presented here, the specific fluorochromes used to render the bacteria fluorescent include deoxyribonucleic acid (DNA)-specific stain 4',6-diamidino-2-phenylindole dihydrochloride (DAPI) [9]. This stain has an absorbance maximum at $340 \mathrm{~nm}$ and a fluorescence maximum at $488 \mathrm{~nm}$. The dye fluoresces when bound to adenine-thymine $(A-T)$ rich regions of DNA, and the fluorescence appears white-blue to blue. This particular fluorochrome is useful when dealing with environmental samples because it also binds to phosphate-rich regions of nonbacterial organic matter with fluorescence emissions appearing yellow [9]. Thus, in the study of bacterial populations of the complex mixtures comprising the test radioactive waste containers, bacteria are readily distinguished from other organic matter. Because both viable and non-viable cells contain DNA, DAPI staining provides total bacterial counts.

The slides are prepared by first obtaining a small volume of the sample. In order to provide accurate measurements of cell numbers in time-dependent experiments, the cells must be fixed immediately after the sample is taken to prevent further growth of cells. Additionally, since the cells will be added to deionized water for staining by DAPI, fixation is also required to prevent cell lysis due to drastic changes in ionic strength. Chemical fixation with formaldehyde causes crosslinking of the polymeric layers of the cell wall, which increases rigidity and stability of the cell, preventing lysis. Approximately $10-40 \mu \mathrm{l}$ of a $1 \mathrm{mg} / \mathrm{ml}$ DAPI solution is added to an aqueous suspension of the bacteria. The sample is placed in the dark for 5-7 minutes. The sample is vacuum-filtered onto a $0.20 \mu \mathrm{m}$ poresize black Poretics membrane. Filtration is performed quantitatively and in a manner such that the sample material is filtered uniformly across the membrane. The membrane is mounted on a microslide and a coverslip placed over the membrane is sealed into place with silicon sealant. Since the membrane contains radioactive or hazardous material, the sealed coverslip provides containment of any contamination which may be present.

Bacteria concentration is determined by the following equation [10]:

\section{cells $/ \mathbf{m l}=[($ avg.cells/field $) \times$ (fields/filter) $\times$ (dilution factor) $] /[$ sample vol. (ml) $]$}

-(avg.cells/field) is the average of bacterial counts from 10-30 different fields of view of the emission image.

-(fields/filter) is an experimentally determined factor which is unique to the filtration apparatus and the microscope objective used. In our studies, this factor is 25,430 fields/filter. -(dilution factor) must be taken into account if the total sample volume is first diluted, and only a portion of the diluted sample volume is used.

-(sample volume) is the total sample volume used in $\mathrm{ml}$. 


\section{RESULTS AND DISCUSSION}

The focus of this paper is to demonstrate the use of epifluorescence microscopy for enumerating microbial populations in the presence of radioactive materials. The results presented from the two studies are shown only as examples of the technique being successfully utilized in radioactive systems $[6,7]$.

In the first study, epifluorescence microscopy with DAPI staining was used to enumerate total bacterial populations in test containers with actual low-level radioactive waste [5]. As discussed previously, the test containers hold different types of radioactive waste that could be
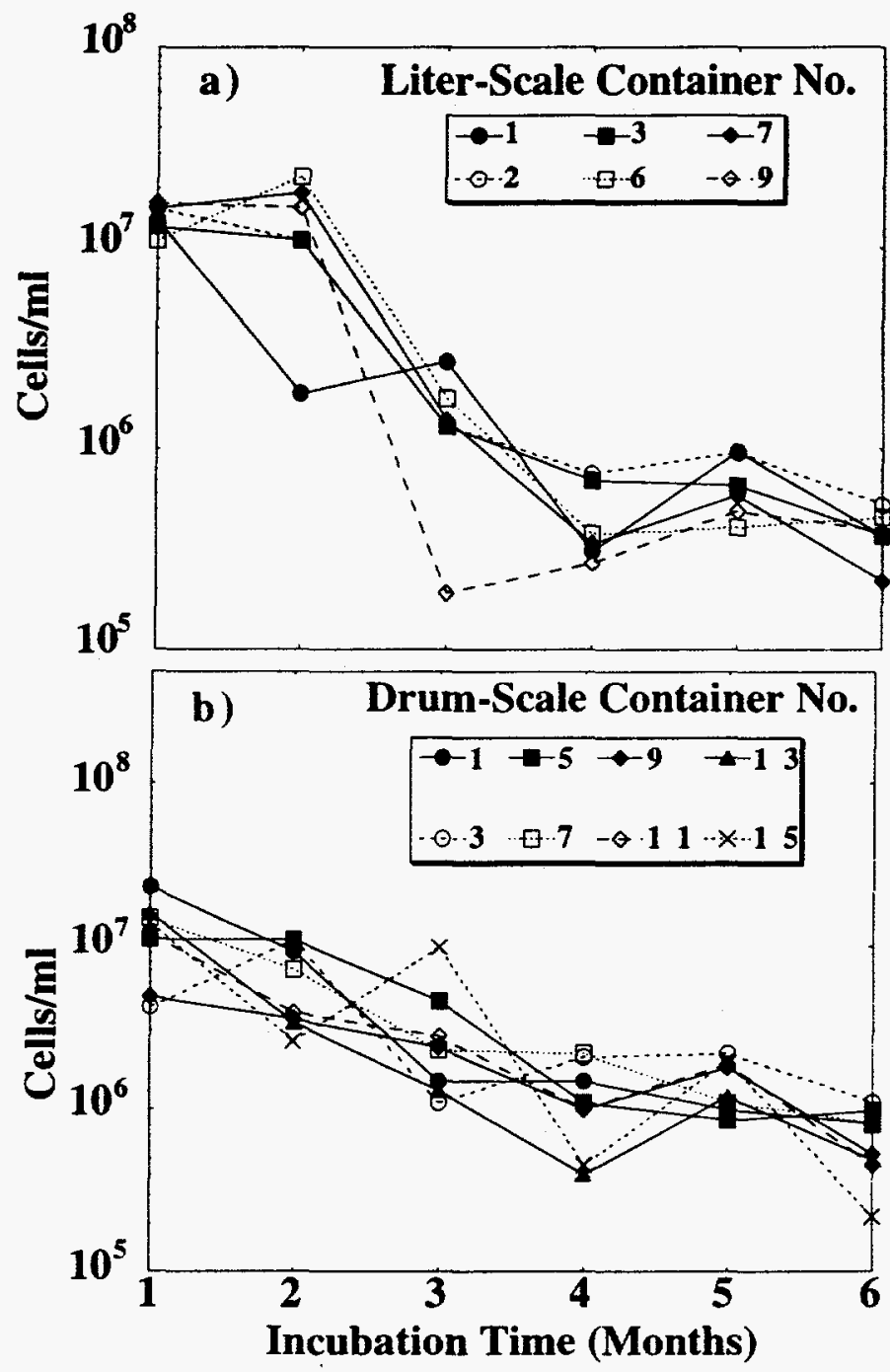

Figure 1. Cell counts measured in a) small (2-3 liter-sized) and b) large (55 gal-sized) test containers versus incubation. Data points are derived from analysis of one slide, 30-50 fields counted per slide. Error bars not shown so as not to complicate the graphs. Error ranged from 15$30 \%$ for the data shown and was derived from taking average from the number of fields counted.

stored in a salt environment. High-ionic strength brine with a mixed bacterial inoculum was added to the test containers [5].

Figure 1 shows the results of total cell counts versus time in selected a) small (2-3 litersized) titanium test containers and selected b) large ( 55 gal-sized) drum test containers. The small 
test containers are comprised of ground-up solidified waste such as crucibles, etc., whereas the large test containers are made up of heterogeneous waste such as tygon tubing, lab coats, etc. As mentioned previously, sludge, salts and cementous materials were also added to the containers. All containers were inoculated with a mixed inoculum. Since the main point of this particular study was to determine bacterial populations within the brine solution with time, the lack of blanks or controls would not bias in any way the bacterial enumeration and would be complicated anyway by the presence of bacteria associated with the added solid materials.

The results show that the total bacterial cell numbers decrease with time which may be a result of cell lysis and death. The decrease may be attributed, however, to cell aggregation or sorption to solid surfaces.

The waste material and/or sludge in the containers settle within the brine to the bottom of the container. For the data shown in Figure 1, the samples analyzed are obtained only from the test container brine solution, so any bacteria associated with the sludge are not detected. It is plausible that the bacteria are removed from the fluid column through aggregation and settling or sorption to test container surfaces. For any viable bacteria present, sorption to sludge material is feasible since this material will provide a source of carbon, nitrogen, sulfur and phosphorus, essential nutrients for bacteria survival. In addition, many bacteria grow and survive more successfully when sorbed to surfaces [11-13]. All of the mentioned nutrients are present in the solid waste, sludge and cementous materials.

To better ascertain the importance of microbial processes in the test containers, research has recently been initiated to determine the viability of the bacteria within the brine solution. Additional studies are aimed at determining the viability and types of bacteria attached to the sludge at the bottom of the test containers. Bacterial viability is suggested since several of the test containers have evolved gases that can be associated specifically with anaerobic denitrifying, or fermenting

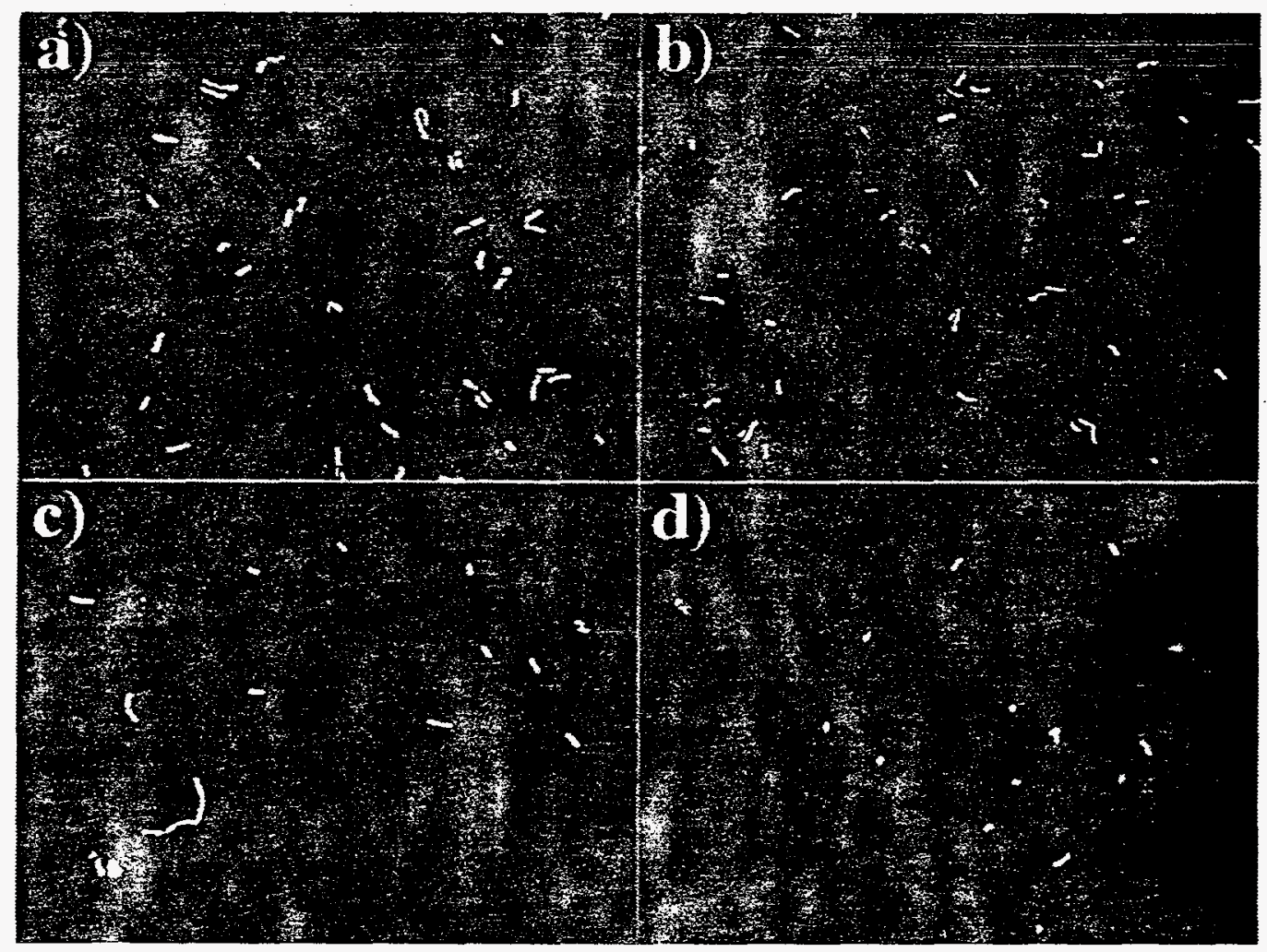

Figure 2. Epifluorescence micrographs of the pure culture at day 1 in its growth cycle. Growth medium contains a) $[\mathrm{Pu}]=0$; b) $[\mathrm{Pu}]=1 \times 10^{-7}$; c) $[\mathrm{Pu}]=1 \times 10^{-6}$; and d) $[\mathrm{Pu}]=1 \times 10^{-5}$. Cells in panel d) are more coccoid in appearance in comparison to rod-shaped bacteria shown in panel a).

Changes to cellular morphology may be a result of cytotoxic effects of $\mathrm{Pu}$ on the bacteria. 
bacterial metabolic processes. As a result, th iditional studies focus on identifying these types of bacteria, and the results will be presented in fuiure reports.

In the second study reported here, total bacterial counts from both a mixed and a pure culture were obtained in order to construct growth curves (cell numbers versus incubation time) of the cultures exposed to various concentrations of actinides [1]. Any appreciable radiological or chemical effects from the actinides appears as variations in the growth curves. Figure 2 is a fluorescence micrograph showing four different fields of view of the pure culture at day 1 in the incubation period as a function of Pu concentration. Plutonium concentrations are as listed in the figure caption. The micrographs show that for the same volume of sample analyzed, there is a decrease in cell numbers, which indicates that growth is increasingly affected as the Pu concentration is increased [1].

Through the images obtained, changes in cellular morphology can be observed and represent another piece of evidence of how $\mathrm{Pu}$ affects the cells. In this study we observed that the morphology of the cells changed with increasing actinide concentration, with the initial rods becoming shorter and more coccoid in appearance with increasing Pu concentration. The changes to cell morphology can be observed readily by comparing the cells in Figure $2 a)([\mathrm{Pu}]=0)$ with those shown in Figure $2 \mathrm{~d}$ ) ([Pu] $=1 \times 10^{-5} \mathrm{M}$ ). The overall bacterial size, from random sampling observations, was reduced in specific cases.

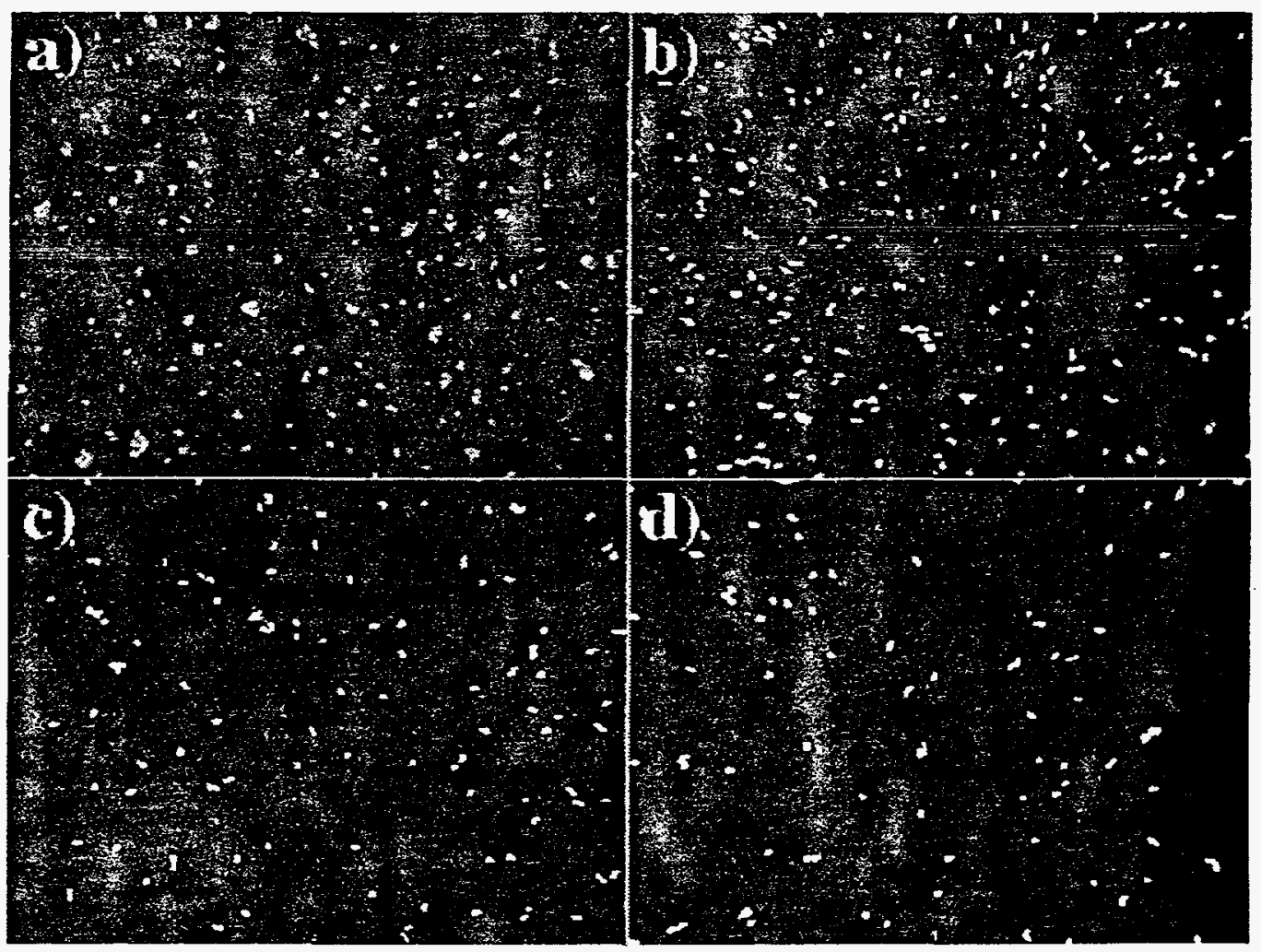

Figure 3. Epifluorescence micrographs of the pure culture at day 7 in its growth cycle. Pu concentrations are as described in Figure 2.

Figure 3 is another fluorescence micrograph showing the same pure culture at day 7 in the incubation period, again as a function of Pu concentration. The decrease in cell numbers with increasing Pu concentration is clearly evident.

These results are shown graphically in Figure 4a) and are in excellent agreement with turbidimetric measurements of the growth medium with time [1]. The agreement between the 
microscopy and turbidity measurements additionally insures that differences in cell counts at day 1 and day 7 are not a result of the variation in cell counts at day 0 [1]. Also shown in Figure 4 are growth curves of the pure culture with different concentrations of Am.

The inset table in each graph shows the radiological activity of the actinides as a function of their soluble concentration in the growth medium. Appropriate control experiments were performed to measure the association (i.e., sorption, precipitation, etc.) of the actinides with the cells [1]. These experiments involved separating the bacteria from the growth medium by $0.20 \mu \mathrm{m}$ filtration and performing liquid scintillation counting (LSC) measurements of $\alpha$-activity in the growth medium before and after filtration [1]. The association of the actinides of the cells could then be determined by LSC difference calculations.

Figure 4 indicates that the presence of Pu indeed has an effect on the bacterial growth cycle as a function of Pu concentration; however, the presence of Am has minimal effect at all

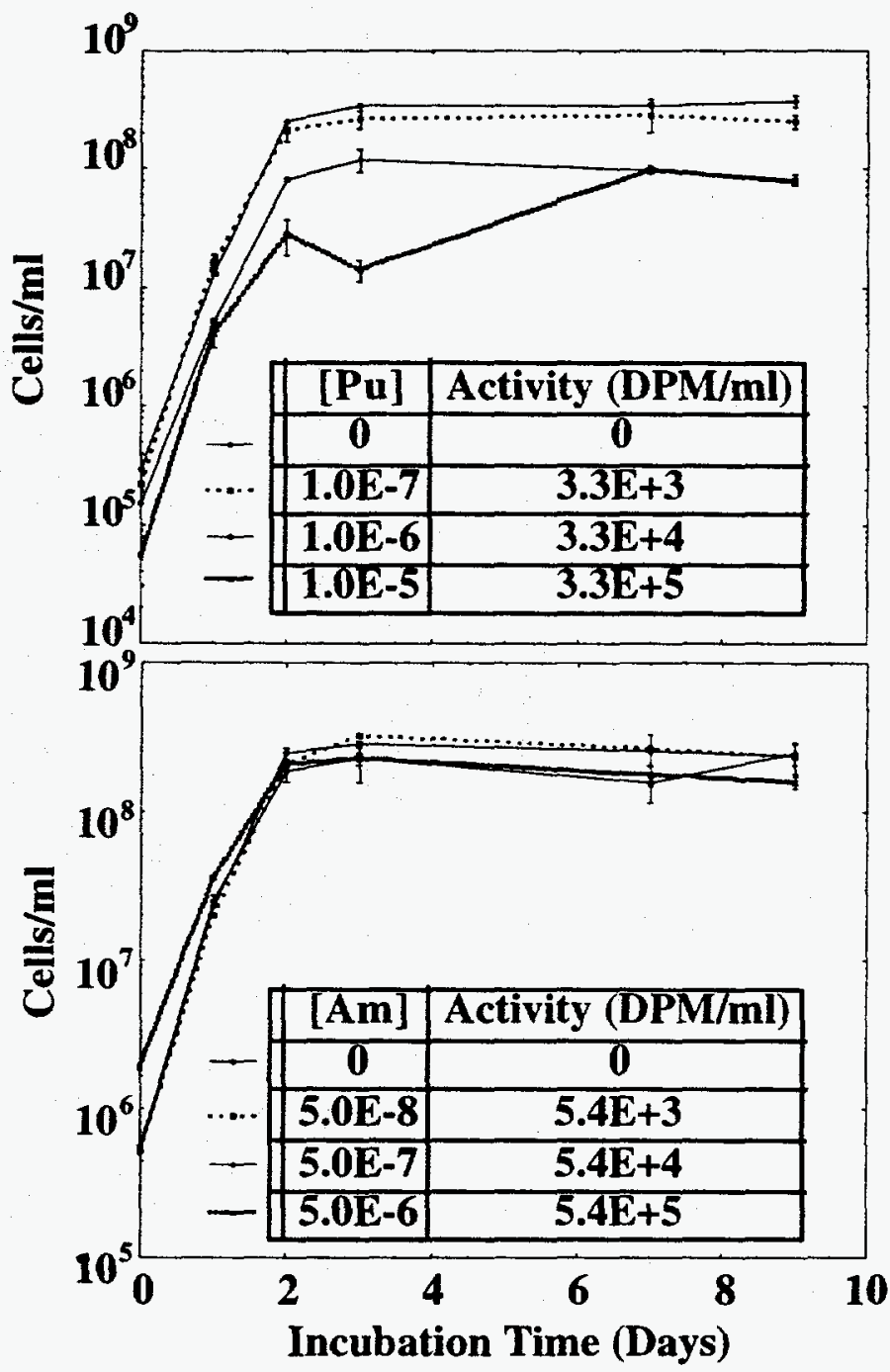

Figure 4. Growth curves of pure culture exposed to different concentrations of a) Pu and b) Am. The data presented is the mean of six sample slides analysis, 5-30 fields counted per slide, and error shown is one Standard Deviation.

concentrations tested. Given that Am has approximately $60 \%$ more $\alpha$-radiolytic activity than Pu in these experiments, the observed effects on bacteria growth in the Pu experiments implies more of a 
chemical versus a radiological effect. However, several more experiments must be performed to confirm the origin of this effect.

\section{SUMMARY}

Epifluorescence microscopy with the fluorescent dye DAPI has been successfully demonstrated to be a useful tool for enumeration of bacterial populations in radioactive environments. The technique offers several advantages over other microbiology methods for determining bacterial numbers in complex, radioactive systems. Total bacterial (viable and nonviable) populations can be enumerated using a single sample. Only small volumes of radioactive or hazardous materials are required, resulting in minimal contaminated waste generation and radiological exposure to the analyst. Also, rapid analysis time is possible and results are available in a minimum period of time, since no incubation is required. The technique, coupled with other complementary studies, allows assessment of the role of bacteria in radioactive waste repository environments with respect to actinide retardation or transport mechanisms, biological interactions with organic materials, and gas generation due to bacteria metabolism.

\section{REFERENCES}

1. B.A. Strietelmeier, J.B. Gillow, C.J. Dodge, M.E. Pansoy-Hjelvik, S.M. Kitten, P.A. Leonard, I.R. Triay, A.J. Francis, H.W. Papenguth, in Radionuclide Speciation in Real Systems, edited by Reed, Clark and Rao (Am. Chem. Soc. Proc., Orlando, FL, 1996), in press.

2. J.B. Gillow, B.A. Strietelmeier, C.J. Dodge, K. Mantione, M. Dunn, A.J. Francis, M.E. Pansoy-Hjelvik, S.M. Kitten, I.R. Triay and H.W. Papenguth, in Radionuclide Speciation in Real Systems, edited by Reed, Clark and Rao (Am. Chem. Soc. Proc., Orlando, FL, 1996), in press;

3. A.J. Francis, Experentia 46, 840 (1990).

4. A.J. Francis and J.B. Gillow, Sandia National Laboratory Report No. SAND93-7036 (1994).

5. M.L.F. Phillips and M.A. Molecke, Sandia National Laboratory Report No. SAND91-2111 (1993).

6. J.B. Gillow and A.J. Francis, Brookhaven National Laboratory Report No. BNL-45756 (1990).

7. A.J. Francis, G. Joshi-Tope, J.B. Gillow and C.J. Dodge, Brookhaven National Laboratory Report No. BNL -49737 (1994).

8. H.G. Kapitza, Microscopy from the Very Beginning, edited by S. Lichtenberg (Carl Zeiss, Oberkochen, 1994), p. 23.

9. R.L. Kepner, Jr. and J.R. Pratt, Microbiol. Rev. 58, 603 (1994).

10. Standard Methods for the Examination of Water and Wastewater, edited by A.E. Greenberg, L.S. Clesceri, A.D. Eaton (American Public Health Association, Washington, 1992), pp. 9-39 9-40.

11. Y. Bar-Or, Experientia 46, 823 (1990).

12. M.P. Dawson, B.A. Humphrey and K.C. Marshall, Curr. Microbiol. 6, 195 (1981).

13. S. Kjelleberg and M. Hermansson, Appl. Environ. Microbiol. 48, 497 (1984). 